\title{
Isolation, Identification and Pathogenicity of Flavobacterium columnare SGM4 in Catfish Clarias batrachus (Linnaeus 1758)
}

\author{
Sudeshna Sarker ${ }^{1}$ (D), Thangapalam Jawahar Abraham ${ }^{1}$ (D)
} 'West Bengal University of Animal and Fishery Sciences, Faculty of Fishery Sciences, Department of Aquatic Animal Health, West
Bengal, India

ORCID IDs of the authors: S.S. 0000-0002-0984-9671;T.J.A. 0000-0003-0581-1307

Please cite this article as: Abraham T.J., Sarker S. Isolation, Identification and Pathogenicity of Flavobacterium columnare SGM4 in Catfish Clarias batrachus (Linnaeus 1758). Eur J Biol 2019; 78(2): 139-146. DOI: 10.26650/EurJBiol.2019.0027

\section{ABSTRACT}

Objective: This study assessed the pathogenicity of Flavobacterium columnare isolated from the gill-rot of catfish, Clarias batrachus in West Bengal, India.

Materials and Methods: The diseased catfish were examined as per standard laboratory practices. F. columnare SGM4 was identified based on the morphological, phenotypic and genotypic characterization. Abrasion-immersion and agar-disc diffusion methods were followed to assess the pathogenicity and antibiotic sensitivity of $F$. columnare, respectively.

Results: The diseased catfish had white gills, tail rot, body discolouration, saddle-back, peeled skin, emaciation, and inflamed kidney. The yellow-pigmented rhizoid colonies from the gills of catfish were identified as F. columnare. Phylogenetically, F. columnare SGM4 branched with F. columnare strains. In abrasion-immersion challenge experiments, F. columnare SGM4 induced considerable mortalities (45\%) in C. batrachus at $7.2 \times 10^{6}$ cells $/ \mathrm{mL}$ at $24-30{ }^{\circ} \mathrm{C}$. In challenged catfish, it caused cutaneous lesions, tail rot, white patches on the gills and degeneration of internal organs. F. columnare strains were highly sensitive to broad-spectrum antibiotics except for sulphafurazole.

Conclusion: Adoption of good nursery practices and appropriate health management measures would help to minimize the development and spread of columnaris disease.

Keywords: Clarias batrachus, Gill-rot, Flavobacterium columnare, Pathogenicity, Antibiotic susceptibility

\section{INTRODUCTION}

Columnaris disease is the most common disease of cultured catfish globally. It is caused by a Gram-negative bacillus Flavobacterium columnare, an acute to chronic bacterial infection, that affects virtually all species of warm water fish $(1,2)$. F. columnare is ubiquitous in the freshwater environment and can cause tragic mortalities in both wild as well as cultured species. The catfish are especially vulnerable to F. columnare infections (3). Mortalities in farmed catfish from columnaris can be as high as $50-60 \%$ (2). It is one of the important bacterial pathogens of freshwater fish and can be of economic importance in catfish farming, particularly in the intensive channel catfish Ictalurus punctatus farming. In the United States catfish industry, it caused an estimated annual loss of US\$ 30 million $(2,4)$. The gills, skin and fins of fish are normally affected by $F$. columnare with varying degrees of clinical manifestation and virulence $(2,4,5)$. The disease is often initiated as an external infection on the body surface, fins or gills, and subsequently developed into yellow-orange lesions along the dorsal midline leading to a condition called saddleback (2).

F. columnare is usually of low pathogenicity and infects fish under stressful conditions. Several authors demonstrated 
divergence in the virulence of $F$. columnare (2,6-8). The columnaris disease outbreaks are heavily dependent on the environmental factors such as the temperature, $\mathrm{pH}$ and hardness of water (3). In aquaculture, the risk for the columnaris is associated with environmental stress. The risk increases with temperature fluctuation, higher feeding rates, more organic loads as well as the increasing stocking densities $(2,8)$. Some strains of this bacterium are highly pathogenic and may cause disease in the absence of documented stress (2). Columnaris disease has been confirmed by molecular characterization of F. columnare in carps such as Catla catla (9), Labeo rohita and Ctenopharyngodon idella (10), goldfish Carassius auratus (11) and climbing perch Anabas testudineus (10) cultured in Indian conditions. The present study aimed at the characterization of F. columnare associated with the gill-rot of diseased Clarias batrachus by phenotypic and molecular means, and the pathogenic potential in C. batrachus fingerlings.

\section{MATERIALS AND METHODS}

\section{Isolation and Phenotypic Characterization of Bacteria}

In February 2015, extensive mortalities in catfish, C. batrachus (Linnaeus, 1758) of 13-14 cm in length and 40-50 g weight were reported from a nursery in Ramchandrapur (Lat. $22^{\circ} 52^{\prime} \mathrm{N}$; Long. $88^{\circ} 28^{\prime} \mathrm{E}$ ), North 24 Parganas district, West Bengal, India. About 1000 catfish juveniles were stocked in cemented tanks $(10 \mathrm{~m} \times$ $10 \mathrm{~m} \times 0.5 \mathrm{~m}$, water depth). The nursery experienced chronic mortalities with 10-20 catfish dying daily. The water temperature fluctuated from 16 to $23^{\circ} \mathrm{C}$ during the mortality period. The morbidity and cumulative mortality were about 65 and $43 \%$, respectively. Water exchange and benzalkonium chloride (50\%) application ( $0.5 \mathrm{ppm}$ ) were attempted thrice. The examination of diseased catfish for gross and clinical signs was done at the site as per Heil (1). The morbid catfish with clinical manifestation of columnaris disease $(n=15)$ were transported to the laboratory in oxygen-filled polythene bags and within 3 hours of collection. Following rinsing in sterile saline and wiping with sterile paper towels, inocula from the catfish gill-rot $(n=5)$ were aseptically streaked onto selective cytophaga agar [SCA] (12) and incubated at $30^{\circ} \mathrm{C}$ for $48 \mathrm{~h}$. Yellow-pigmented rhizoid colonies of $2 \mathrm{~mm}$ size were predominant in all the plates. From all diseased fish, one each of representative yellow-pigmented colony was arbitrarily picked $(n=5)$, purified and characterized on the basis of cell morphology, phenotypic $(13,14)$ and genotypic $(14)$ characters. The genotypic characterization was done for only one rhizoid strain SGM4 (Figure 1).

\section{Molecular and Phylogenetic Characterization}

The 16S rRNA of the rhizoid strain SGM4 was amplified as per the conditions and protocols described in our earlier study (14) using the universal prokaryotic forward (8F) and reverse (1492R) primers (15). The phylogenetic tree was constructed using $3016 \mathrm{~S}$ rRNA gene sequences that included the consensus sequence of the present study (strain SGM4), one type strain and seven nontype strains of F. columnare, 14 type strains of Flavobacterium spp., one each of Chryseobacterium indologenes and Tenacibaculum maritimum. As out-group, the type strains Flectobacillus roseus $(n=1)$, Sphingobacterium thalpophilum $(n=1)$ and Pseudomonas spp. $(n=3)$ were included. The 16S rRNA gene sequences for

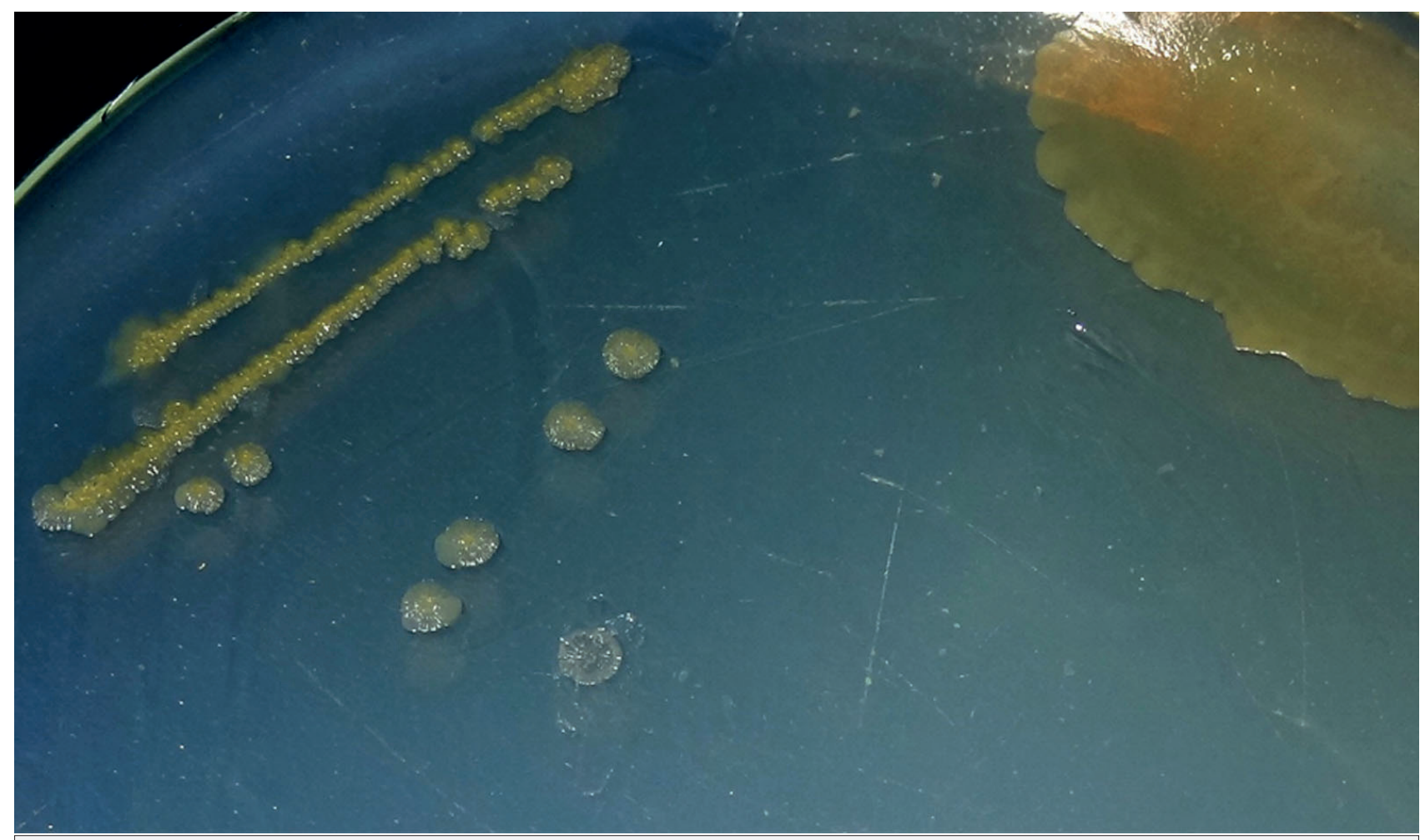

Figure 1. Yellow-pigmented rhizoid colonies of Flavobacterium columnare SGM4 on cytophaga agar 
phylogenetic analysis were collected from the NCBI GenBank and EzBioCloud database (Figure 2). ClustalW 1.6 was followed for the data analysis and multiple alignments. Evolutionary analyses were as per MEGA6 (16).

\section{Pathogenicity of Flavobacterium columnare SGM4}

F. columnare SGM4 cell suspension was prepared and the cell counts determined as described in Sarker et al. (14). Healthy hatcheryraised $C$. batrachus fingerlings $(n=125)$ of weight $3.83 \pm 0.28 \mathrm{~g}$ were procured from a reputed hatchery and transported to the laboratory in oxygen-filled polythene bags. The fingerlings were disinfected in $5 \mathrm{ppm}$ potassium permanganate solution for $5 \mathrm{~min}$ and transferred to 500-L capacity fibreglass reinforced plastic
(FRP) tanks containing 300-L borewell water. The fingerlings were acclimatized for 20 days under optimal conditions and fed twice daily with pellet feed at $4 \%$ of body weight. On alternate days, the faecal matter and other wastes were removed by siphoning and $40-50 \%$ water exchanged.

Pathogenicity of F. columnare SGM4 was tested in C. batrachus fingerlings by the abrasion-immersion method as described in Sarker et al. (14). In brief, healthy fingerlings were stocked at $10 \mathrm{fish} / \operatorname{tank}(58 \times 45 \times 45 \mathrm{~cm})$ and acclimatized in the aerated tank for 3 days at $24-30{ }^{\circ} \mathrm{C}$. The catfish were divided into five groups, viz., A, B, C, D and $E$ in duplicate. Prior to the challenge, the scales of catfish from each tank of groups $A, B$ and $D$ were

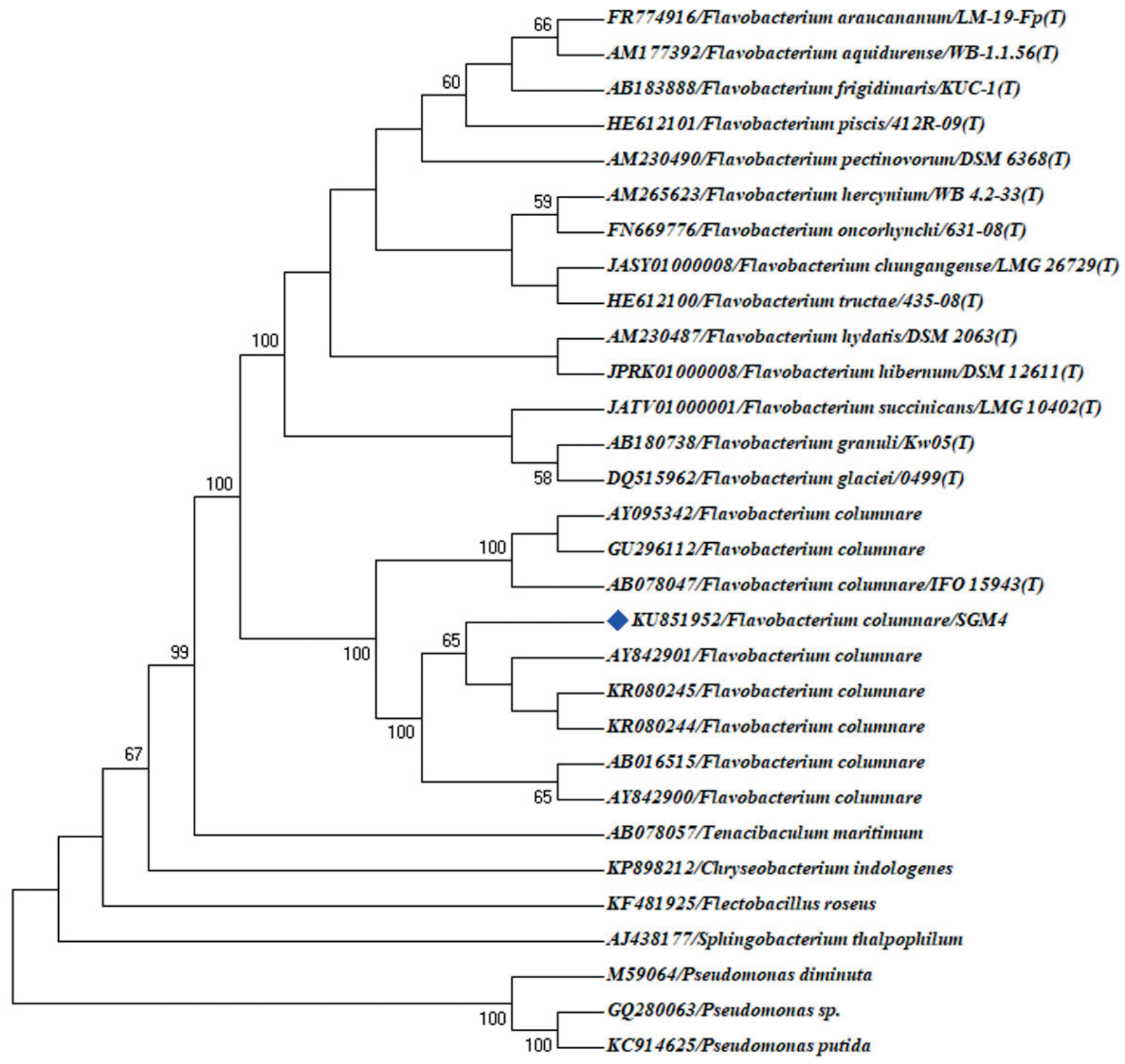

Figure 2. Phylogenetic tree based on the $16 \mathrm{~S}$ rRNA sequence analysis by Neighbor-Joining method. Numbers at nodes indicate bootstrap confidence values (1000 replicates). The GenBank accession number is provided for each species. 
scrapped off gently on one side with a scalpel $1.0 \mathrm{~cm}$ from caudal peduncle towards the pectoral fin (abraded). The abraded catfish of groups $A$ and $B$ were then immersed in F. columnare SGM4 suspensions containing $7.2 \times 10^{6}$ cells $/ \mathrm{mL}, 7.2 \times 10^{5}$ cells $/ \mathrm{mL}$ for 30 min, respectively. The group $C$ was non-abraded and immersed in F. columnare SGM4 suspensions containing $7.2 \times 10^{6}$ cells $/ \mathrm{mL}$ for $30 \mathrm{~min}$. The group $D$ abraded fish was served as a positive control after immersion in $0.85 \%$ saline for $30 \mathrm{~min}$. The fish of all groups were then transferred to the respective tanks. No abrasion or challenge was done to the catfish of group $E$, which served as a negative control. The challenged and control fish groups were observed for the behavioural abnormalities, external signs of infection and mortality for 28 days. Re-isolation of the challenged bacterium from freshly dead catfish was on SCA followed by phenotypic confirmation.

\section{Antibiotic Sensitivity of Flavobacterium columnare}

F. columnare strains $(n=5)$ were screened for their sensitivity to ten broad-spectrum antibiotics, viz., amoxyclav $(30 \mu \mathrm{g})$, chloramphenicol $(30 \mu \mathrm{g})$, ciprofloxacin $(5 \mu \mathrm{g})$, co-trimoxazole $(25 \mu \mathrm{g})$, erythromycin $(15 \mu \mathrm{g})$, gatifloxacin $(5 \mu \mathrm{g})$, gentamicin $(10 \mu \mathrm{g})$, nitrofurantoin $(300 \mu \mathrm{g})$, oxytetracycline $(30 \mu \mathrm{g})$ and sulphafurazole $(300 \mu \mathrm{g})$ by Kirby Bauer agar-disc diffusion technique (17) on cytophaga agar at $30^{\circ} \mathrm{C}$. The antibiotic impregnated discs were procured from HiMedia, India. Interpretation of sensitivity was based on the zone size interpretation chart for Gram-negative bacteria (18).

\section{RESULTS}

\section{Isolation and Phenotypic Characterization of Bacteria}

Inocula from the catfish gill-rot on SCA yielded yellow-pigmented rhizoidal growth within $48 \mathrm{~h}$. The rhizoid colonies were Gramnegative long rods. Five rhizoid strains were characterized phenotypically by conventional biochemical tests, which identified them as F. columnare (Table 1). The strains were, however, identified as Aeromonas salmonicida by the Vitek 2 compact system with a 93\% probability. Minor variation in L-Proline arylamidase activity was noted in one of the strains.

\section{Molecular and Phylogenetic Characterization}

The amplified $16 \mathrm{~S}$ rRNA gene $(\approx 1500 \mathrm{bp}$ ) of the strain SGM4 was edited to a sequence length of $1432 \mathrm{bp}$. Phylogenetic analysis confirmed the strain as a member of the family Flavobacteriaceae. Phylogenetically, the members of the genus Flavobacterium clustered together as a separate clade, distinctly different from other bacteria. The strain SGM4 branched with the type strain F. columnare IFO 15943(T) [NCBI accession number AB078047] and the non-type strains of $F$. columnare with high node value. The 16S rRNA gene sequence of $F$. columnare SGM4 (accession number KU851952) was deposited in NCBI GenBank.

\section{Pathogenicity of Flavobacterium columnare SGM4}

The abraded and immersion challenged C. batrachus fingerlings were sluggish, erratic, hanging and anorectic. In challenged catfish, white patches on the gills, excessive mucus secretion, saddleback, caudal peduncle lesions, tail rot, cutaneous haemorrhages, ulceration in the abraded area, skin discolouration, skin peeling, pale and discoloured kidney and liver, and haemorrhages in the internal organs were observed. About $45 \pm 5 \%$ and $10 \pm 0 \%$ mortalities were noted in abraded groups when challenged at $7.2 \times 10^{6}$ cells $/ \mathrm{mL}$ and $7.2 \times 10^{5}$ cells $/ \mathrm{mL}$ levels, respectively. The internal organs of challenged catfish were haemorrhagic in the later stage (Table 2).

\section{Antibiotic Sensitivity of Flavobacterium columnare}

All F. columnare strains were highly sensitive to amoxyclav, chloramphenicol, ciprofloxacin, gatifloxacin, gentamicin and oxytetracycline. Few strains were resistant to co-trimoxazole $(n=2)$, erythromycin $(n=2)$, nitrofurantoin $(n=1)$ and sulphafurazole $(n=4)$ (Table 3).

\section{DISCUSSION}

The emaciated and diseased catfish had white hues on the gills, gill-rot, tail rot, discoloured skin, saddleback, peeled skin and swollen kidney. Gross and clinical signs observed in diseased catfish signified columnaris disease $(2,5,13)$. The isolation of $F$. columnare from the gill-rot of diseased C. batrachus indicated the opportunistic potential of this bacterium in immunosuppressed catfish during the winter season. The rhizoid type colonies were reportedly virulent to fish $(7,19)$. The low levels of mortalities with 10-20 fish dying daily suggested chronic columnaris disease in catfish at temperatures in the range of $16-23^{\circ} \mathrm{C}$. Vitek 2 compact system identified the tested strains as $A$. salmonicida as the software contained only the database on clinical isolates. Alike our earlier study (14), this identity also contradicted with the conventional and molecular diagnosis. The Vitek- 2 records were, therefore, used for characterizing the strains phenotypically. The phenotypic characteristics of all the F. columnare strains, as shown in Table 1, were almost the same. The Vitek-2 results indicated only minor phenotypic variations among the $F$. columnare strains of diseased catfish. The phylogeny of the strain SGM4 confirmed the bacterium as F. columnare, a member of the family Flavobacteriaceae. It branched with the type strain F. columnare IFO 15943(T) [NCBI accession number AB078047] along with other F. columnare strains with high node value.

Though various challenge routes to induce columnaris disease are available, we chose to follow abrasion and immersion challenge as it gave consistently better results in our earlier study (14). About $45 \pm 5 \%$ and $10 \pm 0 \%$ mortalities were noted in abraded groups when challenged at $7.2 \times 10^{6}$ cells $/ \mathrm{mL}$ and $7.2 \times 10^{5}$ cells $/ \mathrm{mL}$ levels, respectively. No mortalities were noted in non-abraded and immersion challenged catfish and other groups at $24-30^{\circ} \mathrm{C}$. While in the naturally infected population about $65 \%$ morbidity and $43 \%$ cumulative mortalities were recorded at $16-23^{\circ} \mathrm{C}$ in tropical Indian condition. Likewise, in temperate condition, Durborow et al. (20) found that columnaris disease commonly occurs in channel catfish when water temperatures are in the range of $25-32^{\circ} \mathrm{C}$. Columnaris epidemics reportedly occur in water temperatures below $25^{\circ} \mathrm{C}$; even as low as $15^{\circ} \mathrm{C}$, but mortalities and acuteness of disease are significantly less than in higher temperatures $(2,3,8)$. Further, the experiments of Holt et al. (21) revealed that temperatures in excess of $12.2^{\circ} \mathrm{C}$ are required for $F$. columnare induced mortalities in trout and salmon. 
Table 1. Phenotypic characteristics of Flavobacterium columnare strains $(n=5)$ as assessed by conventional biochemical tests and VITEK 2 compact system (bioMérieux, France)

\begin{tabular}{|c|c|c|c|}
\hline Biochemical characteristics & Reaction & Biochemical characteristics & Reaction \\
\hline Conventional biochemical tests & & Vitek 2-Compact system & \\
\hline Colony colour & Yellow & D-Mannose (dMNE) & - \\
\hline Rhizoid colony & + & D-Sorbitol (dSOR) & - \\
\hline Gram reaction & - & D-Tagatose (dTAG) & - \\
\hline Cell morphology, Long rod & + & D-Trehalose (dTRE) & - \\
\hline Gliding motility & + & Ellman (ELLM) & - \\
\hline Oxidase & - & Fermentation/ glucose (OFF) & - \\
\hline Oxidative/Fermentative reaction & $-/-$ & Gamma-glutamyl transferase (GGT) & - \\
\hline Casein hydrolysis & + & Glu-Gly-Arg-arylamidase (GGAA) & - \\
\hline Chondroitin sulphate degradation & - & Glutamyl arylamidase pNA (AGLTp) & - \\
\hline Congo red reaction & + & Glycine arylamidase (GlyA) & - \\
\hline Fibrinogen hydrolysis & - & $\mathrm{H} 2 \mathrm{~S}$ production $(\mathrm{H} 2 \mathrm{~S})$ & - \\
\hline Flexirubin pigment presence & - & L Pyrrolydonyl-arylamidase (PyrA) & - \\
\hline Gelatin hydrolysis & - & L-Arabitol (IARL) & - \\
\hline Growth in selective cytophaga agar\# & + & L-Histidine assimilation (IHISa) & - \\
\hline Vitek 2 Compact system & & Lipase (LIP) & - \\
\hline 5-Keto D-gluconate (5KG) & - & L-Lactate alkalinisation (ILATk) & - \\
\hline Adonitol (ADO) & - & L-Lactate assimilation (ILATa) & - \\
\hline Ala-Phe-Pro-arylamidase (APPA) & - & L-Malate assimilation (IMLTa) & - \\
\hline Alpha-galactosidase (AGAL) & - & L-Proline arylamidase (ProA) & $(-)^{*}$ \\
\hline Alpha-glucosidase (AGLU) & - & Lysine decarboxylase (LDC) & - \\
\hline Beta-alanine arylamidase pNA (BAlap) & - & Malonate (MNT) & - \\
\hline Beta-galactosidase (BGAL) & - & O/129 Resistance (O129R) & - \\
\hline Beta-glucuronidase (BGUR) & - & Ornithine decarboxylase (ODC) & - \\
\hline Beta-glucosidase (BGLU) & - & Palatinose (PLE) & - \\
\hline Beta-xylosidase (BXYL) & - & Phosphatase (PHOS) & - \\
\hline Citrate (sodium) (CIT) & - & Saccharose/Sucrose (SAC) & - \\
\hline Coumarate (CMT) & + & Succinate alkalinisation (SUCT) & - \\
\hline D-Cellobiose (dCEL) & - & Tyrosine arylamidase (TyrA) & - \\
\hline D-Glucose (dGLU) & - & Urease (URE) & - \\
\hline D-Maltose (dMAL) & - & $\beta$-N-acetyl-galactosaminidase (NAGA) & - \\
\hline D-Mannitol (dMAN) & - & $\beta-N-A c e t y l-g l u c o s a m i n i d a s e ~(B N A G)$ & - \\
\hline
\end{tabular}


Table 2. Pathogenicity of Flavobacterium columnare SGM4 by abrasion and immersion challenge

\begin{tabular}{lc}
\hline Treatment group and the challenge dose & Mortality (\%) \\
\hline Group A: Abraded and immersion challenged at $7.2 \times 10^{6}$ cells $/ \mathrm{mL}$ & $45.00 \pm 5.00$ \\
\hline Group B: Abraded and immersion challenged at $7.2 \times 10^{5}$ cells $/ \mathrm{mL}$ & $10.00 \pm 0.00$ \\
\hline Group C: Non-abraded and immersion challenged at $7.2 \times 10^{6} \mathrm{cells} / \mathrm{mL}$ & $0.00 \pm 0.00$ \\
\hline Group D: Abraded and immersion in $0.85 \%$ saline & $0.00 \pm 0.00$ \\
\hline Group E: Neither abraded nor challenged & $0.00 \pm 0.00$
\end{tabular}

Table 3. Antibiotic-resistance in Flavobacterium columnare strains $(n=5)$ isolated from columnaris diseased catfish Clarias batrachus

\begin{tabular}{|c|c|c|c|c|}
\hline \multirow{2}{*}{ Antibiotic ( $\mu \mathrm{g} / \mathrm{disc})$} & \multicolumn{2}{|c|}{ Interpretation of zone size (in $\mathrm{mm}$ ) } & \multirow{2}{*}{$\begin{array}{l}\text { Numbers } \\
\text { resistant }\end{array}$} & \multirow{2}{*}{$\begin{array}{l}\text { Numbers } \\
\text { sensitive }\end{array}$} \\
\hline & Resistant ( $\leq$ ) & Sensitive ( $\geq$ ) & & \\
\hline Amoxyclav (30) & 13 & 18 & 0 & 5 \\
\hline Chloramphenicol (30) & 12 & 18 & 0 & 5 \\
\hline Ciprofloxacin (5) & 15 & 21 & 0 & 5 \\
\hline Co-trimoxazole (25) & 10 & 16 & 1 & 4 \\
\hline Erythromycin (15) & 13 & 23 & 1 & 4 \\
\hline Gatifloxacin (5) & 14 & 18 & 0 & 5 \\
\hline Gentamicin (10) & 12 & 15 & 0 & 5 \\
\hline Nitrofurantoin (300) & 14 & 17 & 1 & 4 \\
\hline Oxytetracycline (30) & 11 & 15 & 0 & 5 \\
\hline Sulphafurazole (300) & 12 & 17 & 4 & 1 \\
\hline
\end{tabular}

With the increase in water temperature, the mortalities reduced and fish became almost normal. These findings indicated that temperature can have a strong effect on the virulence of F. columnare in the culture environment and presumably on disease progression. In other fish pathogens also the growth of bacteria at higher-than-optimal temperature resulted in decreased virulence (8). Abrasion and low temperature exacerbated the rate of infection, which endorse the findings of Moyer and Hunnicutt (22) in zebrafish Danio rerio. In abrasion-bath treatment with $F$. columnare, they recorded $\mathrm{LD}_{50}$ values in the range of $1.1 \times 10^{6}$ $1.1 \times 10^{7} \mathrm{cfu} / \mathrm{mL}$. In another study, Nayak et al. (23) recorded the $\mathrm{LD}_{50}$ values of $F$. columnare in Cirrhinus mrigala fry in the range of $3.0 \times 10^{5}-9.0 \times 10^{6} \mathrm{cfu} / \mathrm{mL}$ by immersion assay. In contrast, Swain et al. (24) recorded no mortalities in non-abraded $L$. rohita fingerlings at a challenge dose of $10^{6}-10^{8} \mathrm{cfu} / \mathrm{mL}$ in immersion challenge study with F. branchiophilum. The experimental challenge results of this study displayed that the gill associated F. columnare SGM4 can induce mortalities in catfish in conjunction with skin damages. In later stages, the development of haemorrhages in the internal organs of challenged catfish indicated a septicemic condition, which supported the study of Decostere et al. (6).

All $F$. columnare strains were highly sensitive to most of the tested antibiotics. Likewise, Sarker et al. (25) recorded highly sensitive Flavobacterium spp. in carps of sewage-fed farms in West Bengal, India. They also recorded Flavobacterium spp. resistant to erythromycin, co-trimoxazole, oxytetracycline and nitrofurantoin with multidrug resistance index ranging from 0.000 to 0.667 . Contrarily, 97 and $100 \%$ of the F. columnare strains were regarded as susceptible to sulfadimethoxine and ormetoprim $(5: 1)$ and oxytetracycline, respectively (12). Many earlier studies also reported no exceptional resistance to antimicrobial drugs among the environmental Flavobacterium strains $(23,26,27)$.

\section{CONCLUSION}

In tropical Indian condition, water temperature and challenge mode induced variations in mortalities due to F. columnare infection were noted. Though the F. columnare strains were 
highly sensitive to antibiotics, with the emergence of antibacterial resistance, the effective preventive measures are warranted. Management measures such as maintenance of optimal stocking densities and water quality parameters, physical removal of biofilm on tank surfaces, adoption of good nursery hygiene, sanitation, and other health management measures would help to minimize the development and spread of columnaris disease.

Peer-review: Externally peer-reviewed.

Author Contributions: Concept:T.J.A; Design:T.J.A; Supervision: T.J.A.; Resource: T.J.A., S.S.; Materials: T.J.A., S.S.; Data Collection and/or Processing: S.S.; Analysis and/or Interpretation: S.S., T.J.A.; Literature Search: S.S.; Writing: S.S., T.J.A.; Critical Reviews: T.J.A.

Ethics Committee Approval: All the experimental protocols with catfish as an experimental animal were approved by the Ethical Committee, WBUAFS, Kolkata, India.

Conflict of Interest: The authors have no conflict of interest to declare.

Financial Disclosure: The research work was supported by the Indian Council of Agricultural Research (Grant F. 10(12)/2012-EPD dated 23.03.2012), Government of India, New Delhi under the Niche Area of Excellence program.

Acknowledgement: The authors thank the Vice-Chancellor, West Bengal University of Animal and Fishery Sciences, Kolkata for providing necessary facilities to carry out the work.

\section{REFERENCES}

1. Heil N. National wild fish health survey-laboratory procedures manual. US Fish and Wildlife Service. Warm Springs, GA. 2009.

2. Declercq AM, Haesebrouck F, Van den Broeck W, Bossier P, Decostere A. Columnaris disease in fish: a review with emphasis on bacterium-host interactions. Vet Res 2013; 44(1): 1-7.

3. Zhou T, Yuan Z, Tan S, Jin Y, Yang Y, Shi H et al. A review of molecular responses of catfish to bacterial diseases and abiotic stresses. Front Physiol 2018; 9:1113.

4. Shoemaker CA, Olivares-Fuster $\mathrm{O}$, Arias $\mathrm{CR}$, Klesius $\mathrm{PH}$. Flavobacterium columnare genomovar influences mortality in channel catfish (Ictalurus punctatus). Vet Microbiol 2008; 127(3-4): 353-9.

5. Loch TP, Faisal M. Emerging flavobacterial infections in fish: a review. J Adv Res 2015; 6(3): 283-300.

6. Decostere A, Ducatelle R, Haesebrouck F. Flavobacterium columnare (Flexibacter columnaris) associated with severe gill necrosis in koi carp (Cyprinus carpio L). Vet Rec 2002; 150(22): 694-5.

7. Kunttu HM, Jokinen El, Valtonen ET, Sundberg LR. Virulent and non-virulent Flavobacterium columnare colony morphologies: characterization of chondroitin AC lyase activity and adhesion to polystyrene. J Appl Microbiol 2011; 111(6): 1319-26.

8. Ashrafi R, Bruneaux M, Sundberg LR, Pulkkinen K, Valkonen J, Ketola T. Broad thermal tolerance is negatively correlated with virulence in an opportunistic bacterial pathogen. Evol Appl 2018; 11(9): 1700-14.
9. Verma DK, Rathore G. Molecular characterization of Flavobacterium columnare isolated from a natural outbreak of columnaris disease in farmed fish, Catla catla from India. J Gen Appl Microbiol 2013; 59(6): 417-24.

10. Patra A, Sarker S, Banerjee S, Adikesavalu H, Biswas D, Abraham TJ. Rapid detection of Flavobacterium columnare infection in fish by species-specific polymerase chain reaction. J Aquacult Res Development 2016; 7: 9.

11. Verma DK, Rathore G, Pradhan PK, Sood N, Punia P. Isolation and characterization of Flavobacterium columnare from freshwater ornamental goldfish Carassius auratus. J Environ Biol 2015; 36(2): 433-9

12. Hawke JP, Thune RL. Systemic isolation and antimicrobial susceptibility of Cytophaga columnaris from commercially reared channel catfish. J Aquat Ani Health 1992; 4(2): 109-13.

13. Austin B, Austin DA. Bacterial fish pathogens: disease of farmed and wild fish. Fifth ed. Chichester, UK: Springer-Praxis in Aquaculture in Fisheries, Praxis Publication Ltd; 2012.

14. Sarker S, Abraham TJ, Banerjee S, Adikesavalu H, Patra A. Characterization, virulence and pathology of Flavobacterium sp. KG3 associated with gill rot in carp, Catla catla (Ham.). Aquaculture 2017; 468: 579-84.

15. Eden PA, Schmidt TM, Blakemore RP, Pace NR. Phylogenetic analysis of Aquaspirillum magnetotacticum using polymerase chain reaction-amplified $16 \mathrm{~S}$ rRNA-specific DNA. Int J Syst Evol Microbiol 1991; 41(2): 324-5.

16. Tamura K, Stecher G, Peterson D, Filipski A, Kumar S. MEGA6: molecular evolutionary genetics analysis version 6.0. Mol Biol Evol 2013; 30(12): 2725-9.

17. Bauer AW, Kirby WM, Sherris JC, Turck M. Antibiotic susceptibility testing by a standardized single disk method. Am J Clin Pathol 1966; 45: 493-6.

18. CLSI, Performance Standards for Antimicrobial Disk Susceptibility Tests, Approved Standard, Seventh ed. CLSI document M02-A11. Clinical and Laboratory Standards Institute, 950 West Valley Road, Suite 2500, Wayne, Pennsylvania 19087, USA. 2012.

19. Kunttu HM, Suomalainen LR, Jokinen El, Valtonen ET. Flavobacterium columnare colony types: connection to adhesion and virulence? Microb Pathog 2009; 46(1): 21-7.

20. Durborow R, Thune R, Hawke J, Camus A. Columnaris disease: a bacterial infection caused by Flavobacterium columnare. Southern Regional Aquaculture Center, Publication No. 479. Stoneville, Mississippi, US Department of Agriculture, Stoneville, Mississippi. 1998.

21. Holt R, Sanders J, Zinn J, Fryer J, Pilcher K. Relation of water temperature to Flexibacter columnaris infection in steelhead trout (Salmo gairdneri), coho (Oncorhynchus kisutch) and chinook (O. tshawytscha) salmon. J Fish Res Board Can 1975; 32(9):1553-59.

22. Moyer TR, Hunnicutt DW. Susceptibility of zebrafish Danio rerio to infection by Flavobacterium columnare and F. johnsoniae. Dis Aquatic Org 2007; 76(1): 39-44.

23. Nayak KK, Pradhan J, Das BK. Characterization, pathogenicity, antibiotic sensitivity and immune response of Flavobacterium columnare isolated from Cirrhinus mrigala and Carassius auratus. Int J Curr Microbiol Appl Sci 2014; 3(11): 273-87.

24. Swain P, Mishra S, Dash S, Nayak SK, Mishra BK, Pani KC, Ramakrishna R. Association of Flavobacterium branchiophilum in bacterial gill disease of Indian major carps. Indian J Anim Sci 2007; 77(7): 646-9. 
Eur J Biol 2019; 78(2): 139-146

Sarker and Abraham. Columnaris Disease in Catfish

25. Sarker S, Abraham TJ, Patra A. Prevalence of diseases caused by Flavobacterium spp. and other opportunistic bacteria in carps of sewage-fed farms in West Bengal, India. J Fish 2019; 7(1): 663-70.

26. Saha $P$, Chakrabarti T. Flavobacterium indicum sp. nov., isolated from warm spring water in Assam, India. Int J Syst Evol Microbiol. 2006; 56(11): 2617-21.
27. Park M, Ryu SH, Vu TH, Ro HS, Yun PY, Jeon CO. Flavobacterium defluvii sp. nov., isolated from activated sludge. Int J Syst Evol Microbiol. 2007; 57(2): 233-7. 